\title{
Persistent lumbar radicular and low back pain; impact of genetic variability versus emotional distress
}

\author{
Siri Bjorland ${ }^{1,2^{*}}$, Johannes Gjerstad ${ }^{3,4}$, Elina Schistad ${ }^{2}$, David M. Swanson ${ }^{5}$ and Cecilie Røe ${ }^{1,2}$
}

\begin{abstract}
Objective: Earlier studies documenting the effect of candidate genes on recovery have seldom taken into consideration the impact of emotional distress. Thus, we aimed to assess the modifying effect of emotional distress on genetic variability as a predictor for pain recovery in lumbar radicular (LRP) and low back pain (LBP).

Results: The study population comprised 201 patients and mean age was 41.7 years. The significant association between MMP9 rs $17576(B=0.71,95 \% \mathrm{Cl} 0.18$ to $1.24, p=0.009)$ and pain recovery remained statistically significant after adjusting for pain intensity at baseline, age, gender, smoking, body mass index, pain localization and emotional distress $(B=0.68,95 \% C l 0.18$ to $1.18, p=0.008)$. In contrast, the association between OPRM1 $(B=-0.85,95 \% C l$ -1.66 to $-0.05, p=0.038)$ and pain recovery was abolished in the multivariate analysis $(B=-0.72,95 \% \mathrm{Cl}-1.46$ to $0.02, p=0.058$ ). Hence, MMP9 rs 17576 and emotional distress independently seem to predict persistent back pain. The predictive effect of OPRM1 rs179971 with regard to the same outcome is probably dependent on other factors including emotional processing.
\end{abstract}

Trial registration The Regional Committee for Medical Research and Ethics reference number 2014/1754

Keywords: Low back pain, Lumbar radicular pain, Emotional distress, Genetic variability

\section{Introduction}

Persistent low back pain (LBP) has a point prevalence of $30 \%$ and creates a substantial personal and financial public burden globally [1-6]. Lumbar radicular pain (LRP), also referred to as sciatica, accounts for $5-10 \%$ of these LBP conditions. Although most back disorders are benign, many patients have a slow recovery [7-9]. In patients with pain, symptoms often tend to be associated with each other, and back pain may be only one of several possible symptoms of general frailty [10]. Psychological factors are of major importance for poor recovery and transition into chronic pain [11, 12]. Actually, many patients focus too much on their bodily symptoms such as dizziness, fatigue or insomnia. Such symptoms in absence of specific diseases in combination with bad

\footnotetext{
*Correspondence: sibjorl@online.no

2 Department of Physical Medicine and Rehabilitation, Oslo University Hospital Ullevål, Postboks 4956 Nydalen, 0424 Oslo, Norway

Full list of author information is available at the end of the article
}

mood are often termed emotional distress [11, 12]. Longitudinal studies suggest that major depression increases the risk of developing future chronic pain [13, 14], and a recent study showed that psychological factors such as emotional exhaustion, mental distress, having little surplus, feeling depressed may propagate the spread of pain [15].

Earlier data suggest that the heritability of back pain range from 30 to $45 \%$ [16]. Genetic variability, which is important for degenerative changes, inflammation or pain perception may play a role in both LBP and LRP conditions [17-21]. Genetic variants in genes encoding proteins such as vitamin D receptor (VDR), collagens (COL) and matrix metalloproteinases (MMPs) may affect degeneration of the intervertebral discs $[18,22]$. In addition, the relationship between pain and MMP9, which is also involved in immunomodulation [23], neuromodulation [24], and activation of the epiregulin-PI3K/ AKT/mTOR pathway [25], may affect pain sensitivity. 
Moreover, previous studies indicate that genetic polymorphisms related to inflammation in genes encoding interleukin 1 (IL-1 $\alpha)$, interleukin-1 receptor antagonist (IL-1RN) and interleukin-6 (IL-6) may promote persistent LRP [26-30].

Some of the same genetic polymorphisms may also be associated with supra-spinal neuronal activity including stress-induced depression [31]. Moreover, genetic variability related to opioid, dopaminergic, adrenergic and serotonergic signaling affect perceptual modulation and nociceptive processing [32-34]. For example, genetic variability related to the enzyme catechol-O-methyltransferase (COMT) affects cortical pain processing and the risk of long-lasting pain conditions [35-37]. In addition, several earlier studies have demonstrated a link between genetic variability in the gene encoding opioid receptor mu 1 (OPRM1) and pain recovery in LRP patients [3840]. Finally, the OPRM1 variant may be associated with attenuated hypothalamic-pituitary-adrenal (HPA) axis responses to stress [41]. The OPRM1 variant is also associated with personality traits [42] and subjective health complaints [39].

Taken together, these observations and similar data from other studies suggest that genetic factors linked to pain recovery, may be associated with peripheral inflammation-but also neuronal activity in brain regions associated with emotions. In addition, recent data from our group have documented a robust association between the MMP9 rs17576 as well as OPRM1 rs1799971 variants and pain recovery [40]. Hence, the aim of the present study was to examine the modifying effect of emotional distress on the association between genetic variability and pain recovery.

\section{Main text}

\section{Study design and study population}

The dataset comprises two ongoing prospective cohorts, which are merged after inclusion but before 5-year follow-up. The methods are previous thoroughly described in our publication in PAIN; "Genetic predictors of recovery in low back and lumbar radicular pain" [40]. This study comprises a subsample of patients from this cohort. This subsample emerges from the Oslo University Hospital (OUH) Ullevaal due to assessment of emotional distress only in this hospital. In total, 275 patients with lumbar radicular pain (LRP) or low back pain (LBP) were recruited between 2007 and 2009. The inclusion criteria in both cohorts was age between 18 and 60 years, and exclusion criteria were specific spinal pathology, generalized musculoskeletal pain, inflammatory rheumatic diseases, diabetic polyneuropathy or serious diseases.

The study was conducted in accordance with the Helsinki Declaration. The Regional Committee for Medical
Research Ethics (reference number 2014/1754) and the Norwegian Social Science Data Service approved the study protocol and all participants gave their written informed consent at baseline and at 5-year follow-up.

\section{Outcome measures}

Emotional distress was assessed using a short version of Hopkins Symptoms Check List (HSCL-10), 4-point scale, where $1=$ no complains, $2=$ some complaints, $3=$ moderate complaints and $4=$ many complaints. The scores summarize and divide on the number of answered questions, with a mean score $>1.85$ being compatible with emotional distress symptoms present [43].

Pain intensity was recorded using the visual analogue scale (VAS) with anchor values from 0 (no pain) to 10 (worst possible pain) at rest during the last week at baseline and at 5 -year follow-up. A cut off $\geq 3.5$ is defined as moderate pain [44].

\section{Genotyping}

In patients with LRP, genomic DNA was collected at baseline and extracted from whole blood cells using a FlexiGene DNA isolation kit (Qiagen), whereas in patients with LBP genomic DNA was collected at 5-year follow up and extracted from saliva using an Oragene DNA sample collection kit (DNA Genotech Inc., California, USA) according to the manufacturer's instructions. SNP genotyping was carried out using predesigned TaqMan SNP genotyping assays (Applied Biosystems). Genotypes were determined using the SDS 2.2 software (Applied Biosystems). Phase v.2.1.1 was used to define the COMT haplotypes. Approximately $10 \%$ of the samples were re-genotyped and the concordance rate was $100 \%$.

\section{Genetic variants and statistical analysis}

Descriptive statistics, t-test and Chi-square test were applied to describe the patients at baseline and 5-year follow-up and evaluate differences between LBP and LRP. Univariate linear regression analysis was performed to estimate the correlation between the eight genetic variants (VDR, COL11, MMP1, MMP9, IL-1 $\alpha$, IL-1RN, OPRM1 and COMT) and pain (VAS) at 5-year follow-up. Further on, we adjusted for emotional distress (HSCL-10) at baseline in the analysis to evaluate the impact of the psychosocial factor. Univariate linear regression analysis also performed to estimate the correlation between emotional distress and pain (VAS) at 5-year follow-up. Significant genetic variants p level $<0.05$ were included in multivariable linear regression models where we adjusted for pain intensity at baseline, age, gender, smoking status (yes or no), body mass index, pain localization (LRP or LBP) and emotional distress. All models were checked 
for collinearity (no collinearity revealed). All statistical analyses were performed using the SPSS (version 22) statistical package. A p-value $<0.05$ was defined as being statistically significant.

\section{Results}

The study population comprised 201 patients, including 92 (46\%) females and 109 males (54\%) with ages of 18 to 59 (mean $41.7 \pm 9.6$ ). An active smoking habit was reported in $34 \%$ of the patients. At baseline, patients in both cohorts reported moderate pain intensity (mean VAS > 3.5) with significantly higher pain in LBP compared to LRP $(p=0.012)$. Regarding emotional distress, the LBP patients reported significantly more complaints (mean HSCL-10>1.85) than the LRP patients (mean HSCL-10<1.85) $(p=0.001)$. At 5-year follow up, the LBP patients reported significantly more pain (mean VAS > 3.5) than the LRP patients (mean VAS $<3.5$ ) $(p<0.001)$. Improvement of emotional distress occurred in both the LBP (mean HSCL-10<1.85) and the LRP groups (mean $\mathrm{HSCl}-10<1.85$ ), but a significant difference in emotional distress was seen $(p=0.035)$. Detailed characteristics of the study population are shown in Table 1.

In univariate linear regression analysis, emotional distress showed a highly significant association with pain intensity at 5-year follow-up $\left(\mathrm{p}<0.001\right.$ and $\left.\mathrm{R}^{2}=0.094\right)$. Regarding the genetic variants, the univariate linear regression analysis showed that the associations between MMP9 rs17576 as well as OPRM1 rs1799971 and pain at 5 years remained statistically significant also in this subsample of patients $\left(p=0.009\right.$ and $R^{2}=0.034, p=0.038$ and $R^{2}=0.022$ ). In the multivariable analysis adjusting for potential confounding effects of baseline pain, pain location (LRP or LBP), age, gender, smoking (yes or no), BMI and emotional distress, only MMP9 rs17576, not OPRM1 rs1799971, remained significant $(\mathrm{p}=0.008)$ (Table 2a, b). In addition, pain location (LRP or LBP) showed a significant association with pain at 5 years in the multivariate model $(\mathrm{p}=0.027)$.

\section{Discussion}

Recent data from our group have demonstrated that both MMP9 rs17576 and OPRM1 rs1799971 may affect 5-year recovery in patients with LRP and LBP [40]. In the present study, we have extended these findings and shown that MMP9 rs17576 remains a significant predictor also when controlling for emotional distress. Thus, the MMP9 rs17576 did not affect pain recovery through emotional distress. In contrast, our data suggested that the OPRM1 rs179971-pain relationship may be more complex - and be dependent on emotional processes. This result may be related to OPRM1 having a role in a common supraspinal neural network processing affective component
Table 1 Characteristics of study population

\begin{tabular}{|c|c|c|c|}
\hline & $\begin{array}{l}\text { LBP } \\
n=106\end{array}$ & $\begin{array}{l}\text { LRP } \\
n=95\end{array}$ & $p$ value \\
\hline \multicolumn{4}{|l|}{ Age } \\
\hline Baseline & $41.4(9.2)$ & $41.9(10.0)$ & $n \cdot s^{\mathrm{a}}$ \\
\hline \multicolumn{4}{|l|}{ Women } \\
\hline Baseline & $39.6(42)$ & $52.6(50)$ & $n \cdot s^{b}$ \\
\hline \multicolumn{4}{|l|}{ Smoke } \\
\hline Baseline & $33.0(35)$ & 34.7 (33) & $n \cdot s^{b}$ \\
\hline 5-year follow up & $31(33)$ & $26(25)$ & $n \cdot s^{b}$ \\
\hline \multicolumn{4}{|l|}{ Pain (VAS) rest } \\
\hline Baseline & $4.7(2.3)$ & $3.8(2.5)$ & $0.012^{\mathrm{a}}$ \\
\hline 5-year follow up & $3.7(2.9)$ & $2.3(2.2)$ & $<0.001^{\mathrm{a}}$ \\
\hline \multicolumn{4}{|l|}{ Pain (VAS) activity } \\
\hline Baseline & $6.3(2.2)$ & $5.7(2.7)$ & $n \cdot s^{a}$ \\
\hline 5-year follow up & $4.7(3.0)$ & $3.2(2.8)$ & $<0.001^{a}$ \\
\hline \multicolumn{4}{|c|}{ Emotional distress (HSCL-10) } \\
\hline Baseline & $2.1(0.6)$ & $1.8(0.5)$ & $0.001^{\mathrm{a}}$ \\
\hline 5-year follow up & $1.7(0.6)$ & $1.5(0.6)$ & $0.035^{\mathrm{a}}$ \\
\hline
\end{tabular}

Continual data: mean (SD). Categorical data: Percent ( $n$ )

n.s not significant

a Unpaired Student's test

b Pearson Chi square test

of pain. Earlier data have also demonstrated that brain regions particular related to the somatosensory component of pain processing may be moderated by genetic variations in the gene encoding OPRM1 [45].

The MMP9 genotype explained $2.2 \%$ of the variation of pain at 5 years. Emotional distress on the other hand explained $9.4 \%$ of the variation of pain at 5 years. These findings support the previous observation that psychological distress is a major predictor for persistent back pain [46]. The LBP patients reported significantly more emotional complaints than the LRP patients both at baseline and 5-year follow-up. However, the data suggested that poorer pain recovery in LBP cannot be explained by the emotional factor alone. Psychological factors at baseline are shown to correlate with persistent LBP [47]. However, earlier data suggest that emotional distress may not be a strong predictor for persistence of low back disability in persons having their first episode of LBP [48]. Nevertheless, to prevent persistent back disability, emotional distress should definitely be considered and treated [48].

In contrast to earlier studies with shorter follow-up [49], the LRP patients showed significantly better pain recovery than the LBP patients, even when controlling for emotional distress. This result suggests that the pain mechanism may change over time. Another explanation could be that LRP patients and LBP patients referred to 
Table 2 Multivariable linear regression with pain intensity at rest 5 years as dependent variable

\begin{tabular}{|c|c|c|c|c|c|}
\hline & Unstan & fficients & Confide & & Sig. \\
\hline & B & SE & Lower & Upper & \\
\hline a) & & & & & \\
\hline MMP9 & 0.68 & 0.25 & 0.18 & 1.18 & 0.008 \\
\hline Age & 0.04 & 0.02 & -0.00 & 0.07 & 0.053 \\
\hline Gender & -0.00 & 0.35 & -0.70 & 0.698 & 1.000 \\
\hline Smoking & 0.25 & 0.37 & -0.48 & 0.97 & 0.856 \\
\hline BMI & 0.01 & 0.03 & -0.05 & 0.07 & 0.856 \\
\hline Pain (VAS) rest baseline & 0.34 & 0.08 & 0.19 & 0.49 & $<0.001$ \\
\hline Pain location (LRP or LBP) & 0.79 & 0.36 & 0.09 & 1.49 & 0.027 \\
\hline Emotional distress (HSCL-10) baseline & 0.74 & 0.32 & 0.10 & 1.38 & 0.023 \\
\hline$R^{2}$ & & & & & 0.26 \\
\hline Adjusted $R^{2}$ & & & & & 0.23 \\
\hline b) & & & & & \\
\hline OPRM1 & -0.72 & 0.38 & -1.46 & 0.02 & 0.058 \\
\hline Age & 0.03 & 0.02 & -0.01 & 0.07 & 0.089 \\
\hline Gender & -0.19 & 0.35 & -0.89 & 0.51 & 0.586 \\
\hline Smoking & 0.33 & 0.37 & -0.40 & 1.06 & 0.367 \\
\hline BMI & 0.01 & 0.03 & -0.05 & 0.07 & 0.742 \\
\hline Pain (VAS) rest baseline & 0.34 & 0.08 & 0.19 & 0.49 & $<0.001$ \\
\hline Pain location (LRP or LBP) & 0.88 & 0.36 & 0.18 & 1.59 & 0.014 \\
\hline Emotional distress (HSCL-10) baseline & 0.64 & 0.33 & -0.01 & 1.28 & 0.052 \\
\hline$R^{2}$ & & & & & 0.25 \\
\hline Adjusted $R^{2}$ & & & & & 0.21 \\
\hline
\end{tabular}

Multivariable linear regression with pain intensity (VAS) at rest at 5 years as dependent variable. a) MMP9 as predictor adjusted for demographic and clinical confounders and controlled for emotional distress. b) OPRM1 as predictor adjusted for demographic and clinical confounders and controlled for emotional distress

specialized healthcare are different from the start [50]. Complex disorders such as LRP and LBP are multifactorial pain conditions [51-53] and whether or not application of results obtained from genetic studies really are ready for clinical use is controversial [54]. However, persistent back pain also includes a biological aetiology [55]. Still, synthesis of clinical and biological research should be important for a more rational management of persistent back pain in the future [56].

In conclusion, the present study showed that MMP9 rs17576 and emotional distress independently predict persistent back pain. OPRM1 rs179971 predicts the same outcome, but for this genetic variant, the effect may be dependent on emotional processing.

\section{Limitations}

Being based on a mix of LRP and LBP patients, the present study has its limitations. We would, however, argue that the subsample of patients included in the present study is representative for the cohort. Still, the mix of LBP and LRP may reduce statistical power. Also, although, the short version of Hopkins Symptoms Checklist (HSCL-10) is a valid instrument [57], it does not distinguish between anxiety, depression, somatization or other psychological symptoms. Hence, HSCL10 may not specify the type of the mental problem in our patients. Finally, the use of the candidate approach will not discover all genetic factors influencing pain.

\section{Abbreviations}

COMT: catechol-O-methyltransferase; COL: collagen; HSCL-10: Hopkins Symptoms Check List; IL 1 a: interleukin 1 alfa; LBP: low back pain; LRP: lumbar radicular pain; MMP: matrix metalloproteinase; OPRM1: opioid receptor mu 1; SNP: single nucleotide polymorphism; VAS: visual analogue scale; VDR: vitamin D receptor.

\section{Acknowledgements}

We thank Kjersti Myhre for collecting data from LBP patients' baseline. We also thank Danijela Miletic, Helene C. H. Olsen and Kathrine Hansen for their help regarding data collection and Aurora Moen and Aqsa Mahmood for performing the genotyping. We would also like to thank all patients for participating in the project.

\section{Authors' contributions}

All authors listed have contributed sufficiently to the project to be included as authors, and all those who are qualified to be authors are listed in the author byline. SB, CR and JG were involved in design of the study. SB and ES participated in interpretation of data and drafting of the manuscript. DMS assisted the statistical analysis in the manuscript. SB, CR and JG wrote the paper. All authors stand by the integrity of the entire work. All authors read and approved the final manuscript. 


\section{Funding}

Siri Bjorland was supported by the University of Oslo (Principal Research Fellowship ID:412597). The funding body is not involved in any part of the scientific process. Other authors have not received financial support.

\section{Availability of data and materials}

The dataset analyzed during the current study are not publicly available due to the data handling rules of health region south east, Norway, but are available from the corresponding author on reasonable request.

\section{Ethical approval and consent to participate}

The Regional Committee for Medical Research Ethics approved the study protocol (The Regional Committee for Medical Research and Ethics reference number 2014/1754) and all the participants gave their written informed consent to participate at baseline and 5-year follow-up.

\section{Consent to publish}

Not applicable.

\section{Competing interests}

The authors declare that they have no competing interests.

\section{Author details Blindern, 0316 Oslo, Norway. \\ Received: 29 June 2019 Accepted: 22 August 2019 \\ Published online: 28 August 2019}

${ }^{1}$ Faculty of Medicine, University of Oslo, Postboks 1078 Blindern, 0316 Oslo, Norway. ${ }^{2}$ Department of Physical Medicine and Rehabilitation, Oslo University Hospital Ullevål, Postboks 4956 Nydalen, 0424 Oslo, Norway. ${ }^{3}$ National Institute of Occupational Health, Gydas vei 8, 0363 Oslo, Norway. ${ }^{4}$ Department of Molecular Bioscience, University of Oslo, Postboks 1066 Blindern, 0316 Oslo, Norway. ${ }^{5}$ Department of Biostatistics, University of Oslo, Postboks 1078

\section{References}

1. Andersson GB. Epidemiological features of chronic low-back pain. Lancet. 1999:354(9178):581-5.

2. Younes M, Bejia I, Aguir Z, Letaief M, Hassen-Zrour S, Touzi M, et al. Prevalence and risk factors of disk-related sciatica in an urban population in Tunisia. Joint Bone Spine. 2006;73(5):538-42.

3. Hoy D, March L, Brooks P, Woolf A, Blyth F, Vos T, et al. Measuring the global burden of low back pain. Best Pract Res Clin Rheumatol. 2010;24(2):155-65.

4. Manchikanti L, Singh V, Datta S, Cohen SP, Hirsch JA, American Society of Interventional Pain P. Comprehensive review of epidemiology, scope, and impact of spinal pain. Pain Physician. 2009;12(4):E35-70.

5. Manchikanti L, Singh V, Falco FJ, Benyamin RM, Hirsch JA. Epidemiology of low back pain in adults. Neuromodulation. 2014;17(Suppl 2):3-10.

6. Hoy DG, Smith E, Cross M, Sanchez-Riera L, Blyth FM, Buchbinder R, et al. Reflecting on the global burden of musculoskeletal conditions: lessons learnt from the global burden of disease 2010 study and the next steps forward. Ann Rheum Dis. 2015:74(1):4-7.

7. Hagen EM, Eriksen HR, Ursin H. Does early intervention with a light mobilization program reduce long-term sick leave for low back pain? Spine (Phila Pa 1976). 2000:25(15):1973-6.

8. Waddell G. Volvo award in clinical sciences. A new clinical model for the treatment of low-back pain. Spine (Phila Pa 1976). 1987;12(7):632-44

9. Mehling WE, Gopisetty V, Acree M, Pressman A, Carey T, Goldberg H, et al. Acute low back pain and primary care: how to define recovery and chronification? Spine (Phila Pa 1976). 2011;36(26):2316-23.

10. Leboeuf-Yde C. Back pain —individual and genetic factors. J Electromyogr Kinesiol. 2004;14(1):129-33.

11. Pincus T, Burton AK, Vogel S, Field AP. A systematic review of psychological factors as predictors of chronicity/disability in prospective cohorts of low back pain. Spine (Phila Pa 1976). 2002;27(5):E109-20.

12. Manchikanti L, Pampati V, Beyer C, Damron K, Barnhill RC. Evaluation of psychological status in chronic low back pain: comparison with general population. Pain Physician. 2002;5(2):149-55
13. Larson SL, Clark MR, Eaton WW. Depressive disorder as a long-term antecedent risk factor for incident back pain: a 13-year follow-up study from the Baltimore Epidemiological Catchment Area sample. Psychol Med. 2004;34(2):211-9.

14. Currie SR, Wang J. More data on major depression as an antecedent risk factor for first onset of chronic back pain. Psychol Med. 2005:35(9):1275-82.

15. Christensen JO, Johansen S, KnardahI S. Psychological predictors of change in the number of musculoskeletal pain sites among Norwegian employees: a prospective study. BMC Musculoskelet Disord. 2017;18(1):140

16. Tegeder I, Lotsch J. Current evidence for a modulation of low back pain by human genetic variants. J Cell Mol Med. 2009;13(8B):1605-19.

17. Bjorland S, Moen A, Schistad E, Gjerstad J, Roe C. Genes associated with persistent lumbar radicular pain; a systematic review. BMC Musculoskelet Disord. 2016;17(1):500.

18. Eskola PJ, Lemmela S, Kjaer P, Solovieva S, Mannikko M, Tommerup N, et al. Genetic association studies in lumbar disc degeneration: a systematic review. PLoS ONE. 2012;7(11):e49995.

19. Battie MC, Videman T, Levalahti E, Gill K, Kaprio J. Heritability of low back pain and the role of disc degeneration. Pain. 2007;131(3):272-80.

20. Kalichman L, Hunter DJ. The genetics of intervertebral disc degeneration. Familial predisposition and heritability estimation. Joint Bone Spine. 2008:75(4):383-7.

21. Omair A, Lie BA, Reikeras O, Brox II. An association study of interleukin 18 receptor genes (IL18R1 and IL18RAP) in lumbar disc degeneration. Open Orthop J. 2012:6:164-71.

22. Song YQ, Sham P, Cheung KMC, Chan D. (iv) Genetics of disc degeneration. Curr Orthop. 2008;22(4):259-66.

23. Wang S, Le Quang T, Chida J, Cisse Y, Yano M, Kido H. Mechanisms of matrix metalloproteinase-9 upregulation and tissue destruction in various organs in influenza A virus infection. J Med Invest. 2010;57(1-2):26-34.

24. Lakhan SE, Avramut M. Matrix metalloproteinases in neuropathic pain and migraine: friends, enemies, and therapeutic targets. Pain Res Treat. 2012:2012:952906.

25. Martin LJ, Smith SB, Khoutorsky A, Magnussen CA, Samoshkin A, Sorge $\mathrm{RE}$, et al. Epiregulin and EGFR interactions are involved in pain processing. J Clin Invest. 2017;127(9):3353-66.

26. Karppinen J, Daavittila I, Noponen N, Haapea M, Taimela S, Vanharanta H, et al. Is the interleukin-6 haplotype a prognostic factor for sciatica? Eur J Pain. 2008:12(8):1018-25.

27. Schistad El, Jacobsen LM, Roe C, Gjerstad J. The interleukin-1alpha gene C>T polymorphism rs 1800587 is associated with increased pain intensity and decreased pressure pain thresholds in patients with lumbar radicular pain. Clin J Pain. 2014;30(10):869-74

28. Moen A, Schistad El, Rygh L, Roe C, Gjerstad J. Role of IL1A rs1800587, IL1B rs1143627 and IL1RN rs2234677 genotype regarding development of chronic lumbar radicular pain; a prospective one-year study. PLOS ONE. 2014;9(9):e107301 (Electronic Resource)

29. Noponen-Hietala N, Virtanen I, Karttunen R, Schwenke S, Jakkula E, Li H, et al. Genetic variations in IL6 associate with intervertebral disc disease characterized by sciatica. Pain. 2005:114(1-2):186-94.

30. Dominguez CA, Kalliomaki M, Gunnarsson U, Moen A, Sandblom G, Kockum I, et al. The DQB1*03:02 HLA haplotype is associated with increased risk of chronic pain after inguinal hernia surgery and lumbar disc herniation. Pain. 2013;154(3):427-33.

31. Tartter M, Hammen C, Bower JE, Brennan PA, Cole S. Effects of chronic interpersonal stress exposure on depressive symptoms are moderated by genetic variation at IL6 and IL1 beta in youth. Brain Behav Immun. 2015;46:104-11.

32. Zubieta JK, Smith YR, Bueller JA, Xu Y, Kilbourn MR, Jewett DM, et al. Regional mu opioid receptor regulation of sensory and affective dimensions of pain. Science. 2001:293(5528):311-5.

33. Zubieta JK, Heitzeg MM, Smith YR, Bueller JA, Xu K, Xu Y, et al. COMT val158met genotype affects mu-opioid neurotransmitter responses to a pain stressor. Science. 2003;299(5610):1240-3.

34. Zubieta JK, Bueller JA, Jackson LR, Scott DJ, Xu Y, Koeppe RA, et al. Placebo effects mediated by endogenous opioid activity on mu-opioid receptors. J Neurosci. 2005;25(34):7754-62. 
35. Diatchenko L, Fillingim RB, Smith SB, Maixner W. The phenotypic and genetic signatures of common musculoskeletal pain conditions. Nat Rev Rheumatol. 2013;9(6):340-50.

36. Diatchenko L, Slade GD, Nackley AG, Bhalang K, Sigurdsson A, Belfer I, et al. Genetic basis for individual variations in pain perception and the development of a chronic pain condition. Hum Mol Genet. 2005:14(1):135-43.

37. Nackley AG, Shabalina SA, Tchivileva IE, Satterfield K, Korchynskyi O, Makarov SS, et al. Human catechol-O-methyltransferase haplotypes modulate protein expression by altering mRNA secondary structure. Science. 2006;314(5807):1930-3.

38. Olsen MB, Jacobsen LM, Schistad El, Pedersen LM, Rygh LJ, Roe C, et al. Pain intensity the first year after lumbar disc herniation is associated with the a118g polymorphism in the opioid receptor Mu 1 gene: evidence of a sex and genotype interaction. J Neurosci. 2012;32(29):9831-4.

39. Hasvik E, lordanova Schistad E, Grovle L, Julsrud Haugen A, Roe C, Gjerstad J. Subjective health complaints in patients with lumbar radicular pain and disc herniation are associated with a sex-OPRM1 A118G polymorphism interaction: a prospective 1-year observational study. BMC Musculoskelet Disord. 2014;15(1):161.

40. Bjorland S, Roe C, Moen A, Schistad E, Mahmood A, Gjerstad J. Genetic predictors of recovery in low back and lumbar radicular pain. Pain. 2017;158:1456-60.

41. Schwandt ML, Lindell SG, Higley JD, Suomi SJ, Heilig M, Barr CS. OPRM1 gene variation influences hypothalamic-pituitary-adrenal axis function in response to a variety of stressors in rhesus macaques. Psychoneuroendocrinology. 2011;36(9):1303-11.

42. Troisi A, Frazzetto G, Carola V, Di Lorenzo G, Coviello M, D'Amato FR, et al. Social hedonic capacity is associated with the A118G polymorphism of the mu-opioid receptor gene (OPRM1) in adult healthy volunteers and psychiatric patients. Soc Neurosci. 2011;6(1):88-97.

43. Strand BH, Dalgard OS, Tambs K, Rognerud M. Measuring the mental health status of the Norwegian population: a comparison of the instruments SCL-25, SCL-10, SCL-5 and MHI-5 (SF-36). Nord J Psychiatry. 2003;57(2):113-8.

44. Boonstra AM, Schiphorst Preuper HR, Balk GA, Stewart RE. Cut-off points for mild, moderate, and severe pain on the visual analogue scale for pain in patients with chronic musculoskeletal pain. Pain. 2014;155(12):2545-50.

45. Bonenberger M, Plener PL, Groschwitz RC, Gron G, Abler B. Polymorphism in the micro-opioid receptor gene (OPRM1) modulates neural processing of physical pain, social rejection and error processing. Exp Brain Res. 2015;233(9):2517-26

46. Croft PR, Papageorgiou AC, Ferry S, Thomas E, Jayson MI, Silman AJ. Psychologic distress and low back pain. Evidence from a prospective study in the general population. Spine (Phila Pa 1976). 1995;20(24):2731-7.

47. Melloh M, Elfering A, Egli Presland C, Roder C, Hendrick P, Darlow B, et al. Predicting the transition from acute to persistent low back pain. Occup Med (Lond). 2011;61(2):127-31.

48. Brage S, Sandanger I, Nygard JF. Emotional distress as a predictor for low back disability: a prospective 12-year population-based study. Spine (Phila Pa 1976). 2007;32(2):269-74.

49. Konstantinou K, Dunn KM. Sciatica: review of epidemiological studies and prevalence estimates. Spine (Phila Pa 1976). 2008;33(22):2464-72.

50. Long DM, BenDebba M, Torgerson WS, Boyd RJ, Dawson EG, Hardy RW, et al. Persistent back pain and sciatica in the United States: patient characteristics. J Spinal Disord. 1996;9(1):40-58.

51. Manek NJ, MacGregor AJ. Epidemiology of back disorders: prevalence, risk factors, and prognosis. Curr Opin Rheumatol. 2005;17(2):134-40.

52. Miranda H, Viikari-Juntura E, Martikainen $R$, Takala EP, Riihimaki H. Individual factors, occupational loading, and physical exercise as predictors of sciatic pain. Spine (Phila Pa 1976). 2002;27(10):1102-9.

53. Rubin DI. Epidemiology and risk factors for spine pain. Neurol Clin. 2007;25(2):353-71.

54. Jakobsdottir J, Gorin MB, Conley YP, Ferrell RE, Weeks DE. Interpretation of genetic association studies: markers with replicated highly significant odds ratios may be poor classifiers. PLoS Genet. 2009;5(2):e1000337.

55. Bush WS, Haines J. Overview of linkage analysis in complex traits. Curr Protoc Hum Genet. 2010;64:1-19.

56. Hancock MJ, Maher CG, Laslett M, Hay E, Koes B. Discussion paper: what happened to the 'bio' in the bio-psycho-social model of low back pain? Eur Spine J. 2011;20(12):2105-10.

57. Haavet OR, Sirpal MK, Haugen W, Christensen KS. Diagnosis of depressed young people in primary health care-a validation of HSCL-10. Fam Pract. 2011;28(2):233-7

\section{Publisher's Note}

Springer Nature remains neutral with regard to jurisdictional claims in published maps and institutional affiliations.
Ready to submit your research? Choose BMC and benefit from:

- fast, convenient online submission

- thorough peer review by experienced researchers in your field

- rapid publication on acceptance

- support for research data, including large and complex data types

- gold Open Access which fosters wider collaboration and increased citations

- maximum visibility for your research: over 100M website views per year

At BMC, research is always in progress.

Learn more biomedcentral.com/submissions 